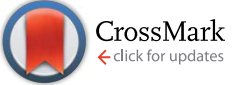

Cite this: RSC Adv., 2017, 7, 1863

\title{
Efficient construction of biologically important functionalized polycyclic spiro-fused carbocyclicoxindoles via an asymmetric organocatalytic quadruple-cascade reaction $\dagger$
}

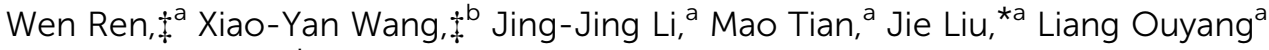 \\ and Jin-Hui Wang*c
}

An efficient construction of highly functionalized polycyclic spiro-fused carbocyclicoxindoles has been developed via an asymmetric organocatalytic quadruple domino reaction of (E)-3-(2hydroxybenzylidene)oxindole derivatives and two molecules of $\alpha, \beta$-unsaturated aldehyde under quadruple iminium-enamine-iminium-enamine catalysis. The complex cascade products bearing a spiro quaternary center and five contiguous stereocenters were obtained in moderate to high yields (up to $90 \%$ ) with good diastereoselectivities (up to $8: 1$ ) and excellent ee values (up to $99 \%$ ee). The structure and absolute configuration of the products were confirmed by NMR spectroscopy and single crystal X-ray analysis. In addition, the biological study showed that these compounds had moderate antitumor activities in the micromolar range.

Received 8th October 2016 Accepted 18th November 2016

DOI: 10.1039/c6ra24910h

www.rsc.org/advances chiral polycyclic derivatives. As a consequence, some multicomponent quadruple cascade reactions involving the formation of four $\mathrm{C}-\mathrm{C}$ bonds and generating multiple stereocenters also have been reported. ${ }^{5}$ However, among them, fewer examples have been reported that construct spiro-fused polycyclic frameworks. Therefore, the development of exquisite higherorder cascade reactions in the construction of more complex spiro-fused polycyclic frameworks with stereocontrolled spiro quaternary centers and multiple chiral centers is highly attractive and in great demand.

Alkylideneoxindoles ( $\mathrm{R}$ groups are usually phenyl, alkyl, ester) as prochiral electrophiles have been used in catalytic asymmetric synthesis of spirooxindoles via different cyclizations such as 1,3-dipolar cycloadditions, Diels-Alder reactions, and cyclopropanation. ${ }^{3 \boldsymbol{d}-\boldsymbol{f} \boldsymbol{k}, \boldsymbol{k}-\boldsymbol{s}, \mathbf{6}}$ In contrast, fewer examples that
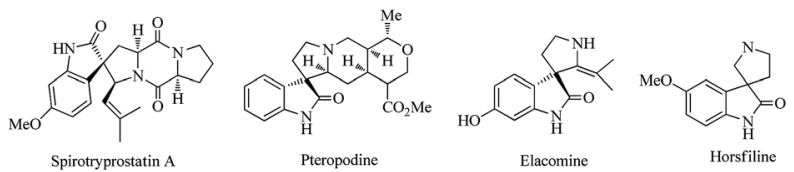

${ }^{a}$ State Key Laboratory of Biotherapy and Cancer Center, West China Hospital, Sichuan
University, Collaborative Innovation Center for Biotherapy, Chengdu 610041, China. E-mail: liujie2011@scu.edu.cn; Fax: +86-028-8550-3817; Tel: +86-028-8550-3817

${ }^{b}$ Analytical \& Testing Center, Sichuan University, Chengdu 610064, China

${ }^{c}$ College of Pharmacy, Xinjiang Medical University, Urumqi 830011, China. E-mail: wangjinhui2015@sina.com

$\dagger$ Electronic supplementary information (ESI) available. CCDC 1040723. For ESI and crystallographic data in CIF or other electronic format see DOI: 10.1039/c6ra24910h

\$ These authors made equal contributions to this work.

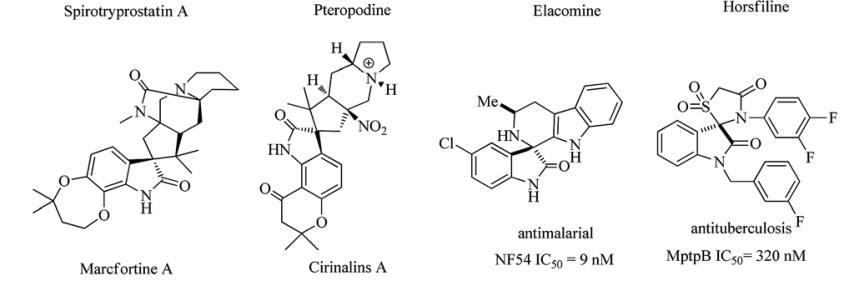

Fig. 1 Examples of natural products, pharmaceutical molecules containing spiro-fused cyclic frameworks. 


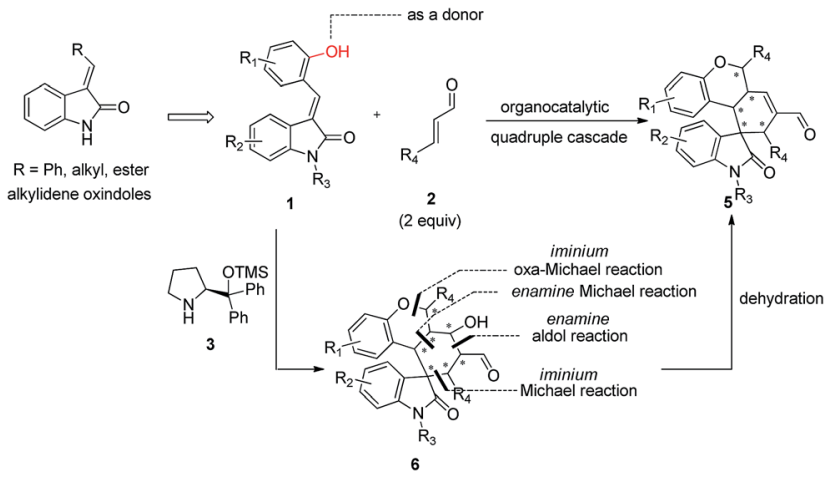

Scheme 1 Organocatalytic quadruple cascade reaction through iminium-enamine-iminium-enamine sequential activation initiated by oxa-Michael addition to construct polycyclic spiro-fused carbocyclicoxindoles.

construct spirooxindoles from alkylideneoxindoles involving quadruple cascade reactions have been reported. This most likely owed to the insufficient reactive sites on the alkylideneoxindoles and the fact organocatalytic domino reactions are unable to proceed. The careful design of substrate by introducing multifunctional group on the substrates could serve as a good starting point to form novel transformations in both reaction sequences and complete the domino reactions. Recently, many double or triple cascade reactions have been initiated by oxa-Michael. ${ }^{7}$ Secondary amines, such as proline and derivatives, were employed in these reactions by their iminium-ion and enamine activation modes for an efficient activation of both donor- and acceptor-type molecules. Inspired by these successes, we reasoned that the introduction of a hydroxy group on the alkylideneoxindoles, as a donor in Michael reaction, might successively perform as nucleophiles and electrophiles, and facilitate the quadruple cascade reactions (Scheme 1). In addition, the quadruple cascade reactions are atom-, time-, step-economic, and can often imitate biosynthetic pathways, all which make them increasingly attractive for the organic chemistry community. ${ }^{8}$ Herein, we envisioned a simple and efficient protocol for quadruple cascade reaction through iminium-enamine-iminium-enamine sequential activation initiated by oxa-Michael addition of phenolic hydroxyl to $\alpha, \beta$-unsaturated aldehyde, as outlined in Scheme 1, to provide a straightforward protocol for the synthesis of polycyclic spiro-fused carbocyclicoxindoles with a spiro quaternary center and five contiguous stereocenters.

\section{Results and discussion}

At the outset of the study, the multifunctional substrate 1a was easily prepared via a Knoevenagel reaction of oxindole and salicylaldehyde. ${ }^{9}$ Then the quadruple domino reaction of $(E)-3-$ (2-hydroxybenzylidene)oxindole 1a (1.0 equiv.) and excess crotonaldehyde 2a (2.44 equiv.), as a simple model substrate was investigated to establish the feasibility of the strategy and optimize the reaction conditions. By using chloroform as solvent at $60{ }^{\circ} \mathrm{C}$ for $12 \mathrm{~h}$, the catalysis of $(S)$-diphenylprolinol
TMS ether $3 a(20 \mathrm{~mol} \%)$ and acetic acid (20 mol\%) gave satisfactory results, and the desired polycyclic spiro-fused carbocyclicoxindoles 5aa, bearing five contiguous stereocenters, was obtained in $60 \%$ yield (Table 1 , entry 1 ). Although the diastereoselectivity was only $1: 1$, the isolation of the quadruple domino product 5 aa by flash chromatography revealed that the two diastereomer with $98 \%$ ee and $90 \%$ ee could be separated from each other. The reaction with $\mathbf{3 a}$ without the acid additive gave no reaction for two days. Other different secondary amine catalysts such $(S)$-diphenylprolinol TES ether $\mathbf{3 b}$ and $(S)$ -

Table 1 Screening of the catalysts, additives, solvents and reaction conditions for the cascade reactions ${ }^{a}$

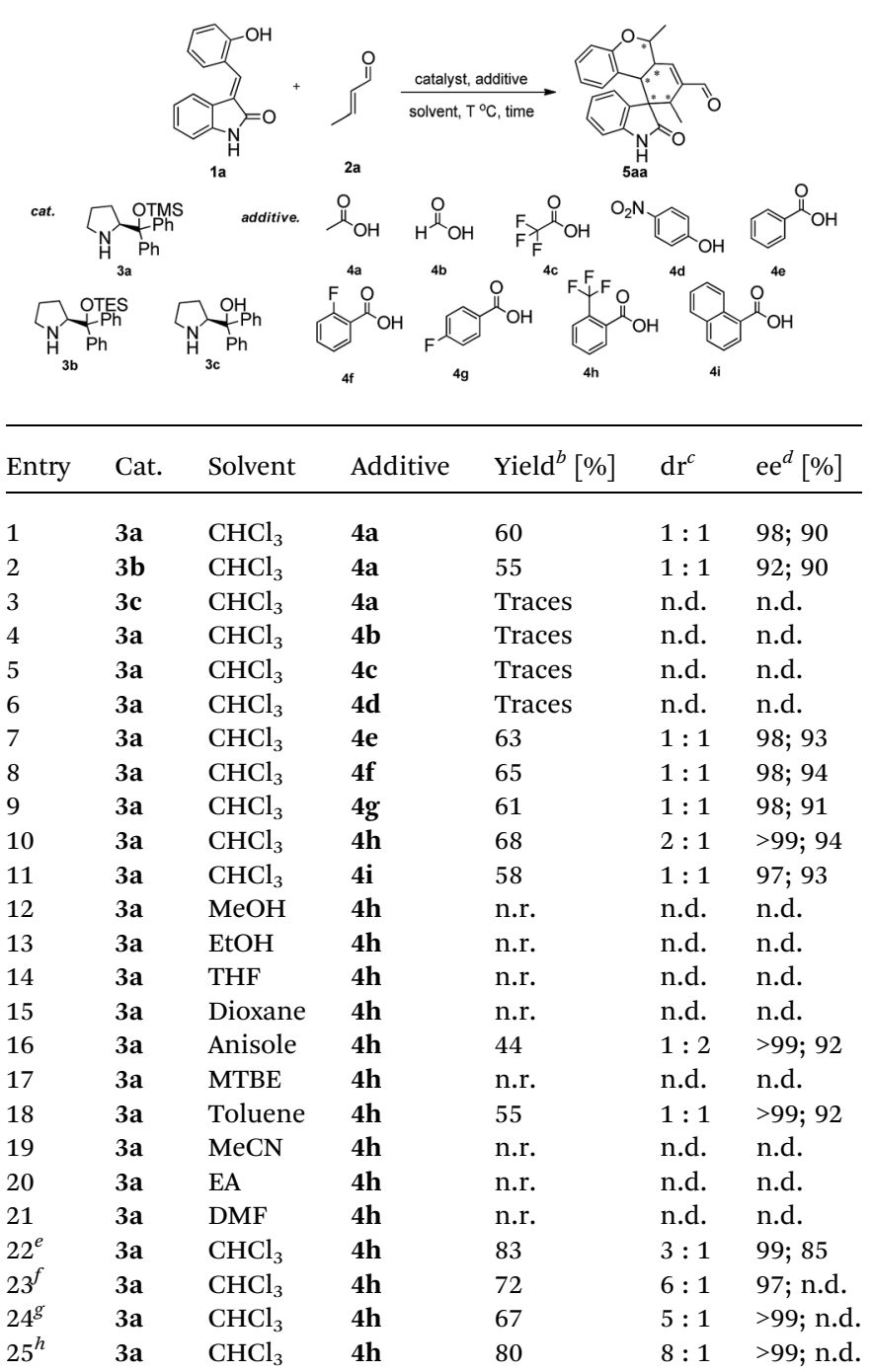

${ }^{a}$ Unless otherwise noted, reactions were performed with $0.1 \mathrm{mmol} 1 \mathrm{1a}$ and $0.244 \mathrm{mmol}(20 \mu \mathrm{L}) 2 \mathrm{a}$ in the presence of catalyst $3(20 \mathrm{~mol} \%)$ and the additive acid or phenol $4(20 \mathrm{~mol} \%)$ in $1.0 \mathrm{~mL}$ of solvent at $60{ }^{\circ} \mathrm{C}$ for $12 \mathrm{~h} .{ }^{b}$ The values are yields of isolated product after silica gel column chromatography. ${ }^{c}$ Determined by ${ }^{1} \mathrm{H}$ NMR on the crude reaction mixture. ${ }^{d}$ Determined by chiral HPLC. ${ }^{e}$ The ratio of catalyst 3a $(20 \mathrm{~mol} \%)$ and additive $4 \mathbf{h}(60 \mathrm{~mol} \%)$ was $1: 3 .^{f}$ The reaction was conducted at $40{ }^{\circ} \mathrm{C}$ for $60 \mathrm{~h} .{ }^{g}$ The reaction was conducted at $25{ }^{\circ} \mathrm{C}$ for $168 \mathrm{~h} .{ }^{h}$ The reaction was conducted at $40{ }^{\circ} \mathrm{C}$ for $24 \mathrm{~h}$, then heated up to $60{ }^{\circ} \mathrm{C}$ for $12 \mathrm{~h}$. MTBE = methyl tert-butyl ether; EA = ethyl acetate; n.r. $=$ no reaction. n.d. $=$ not detected. 
diphenylprolinol 3c were also estimated, no superior result was obtained (Table 1, entries 2-3). To obtain higher yields and diastereoselectivities, some other acids, which probably promoted the formation of iminium ion, were screened (Table 1, entries 4-11). The 2-(trifluoromethyl)benzoic acid $4 \mathbf{h}$ was shown to be suitable for this reaction, affording the product with 2 : 1 diastereoselectivity (Table 1, entry 10). While stronger acids, such as TFA 4c, made reaction sluggish with only trace product (Table 1, entry 5). Subsequently, we performed a short solvent screening (Table 1, entries 12-21). Whereas the reaction in anisole gave a product of reversed configuration (Table 1, entry 16), no conversion could be detected when the reaction was performed in protic and polar solvents (Table 1, entries 12-15, 19-21). Toluene showed a comparable yield and enantiomeric excess of product of 5aa to chloroform but the diastereoselectivity was decreased (Table 1, entry 18). To our delight, we found that the diastereoselectivity could be improved by increasing the ratio of additive $\mathbf{4 h}$ and catalyst $\mathbf{3 a}$ to 3 : 1 (Table 1 , entry 22 the detail see the ESI $\dagger$ ). Lower catalyst loading led to a significant decrease in the yields while higher amounts did not give any remarkable improvement (data not shown). Best results were afforded by adjusting the temperature and prolonging reaction time (Table 1, entry 25). Based on the above results, the optimal condition was found: the reaction was conducted at $40{ }^{\circ} \mathrm{C}$ for $24 \mathrm{~h}$, then heated up to $60{ }^{\circ} \mathrm{C}$ for $12 \mathrm{~h}$, and the quadruple domino product 5 aa was obtained in $80 \%$ yield with $8: 1$ diastereoselectivity and $>99 \%$ ee (major).

Table 2 Scope of the asymmetric quadruple cascade reaction of 1 and $2^{a}$

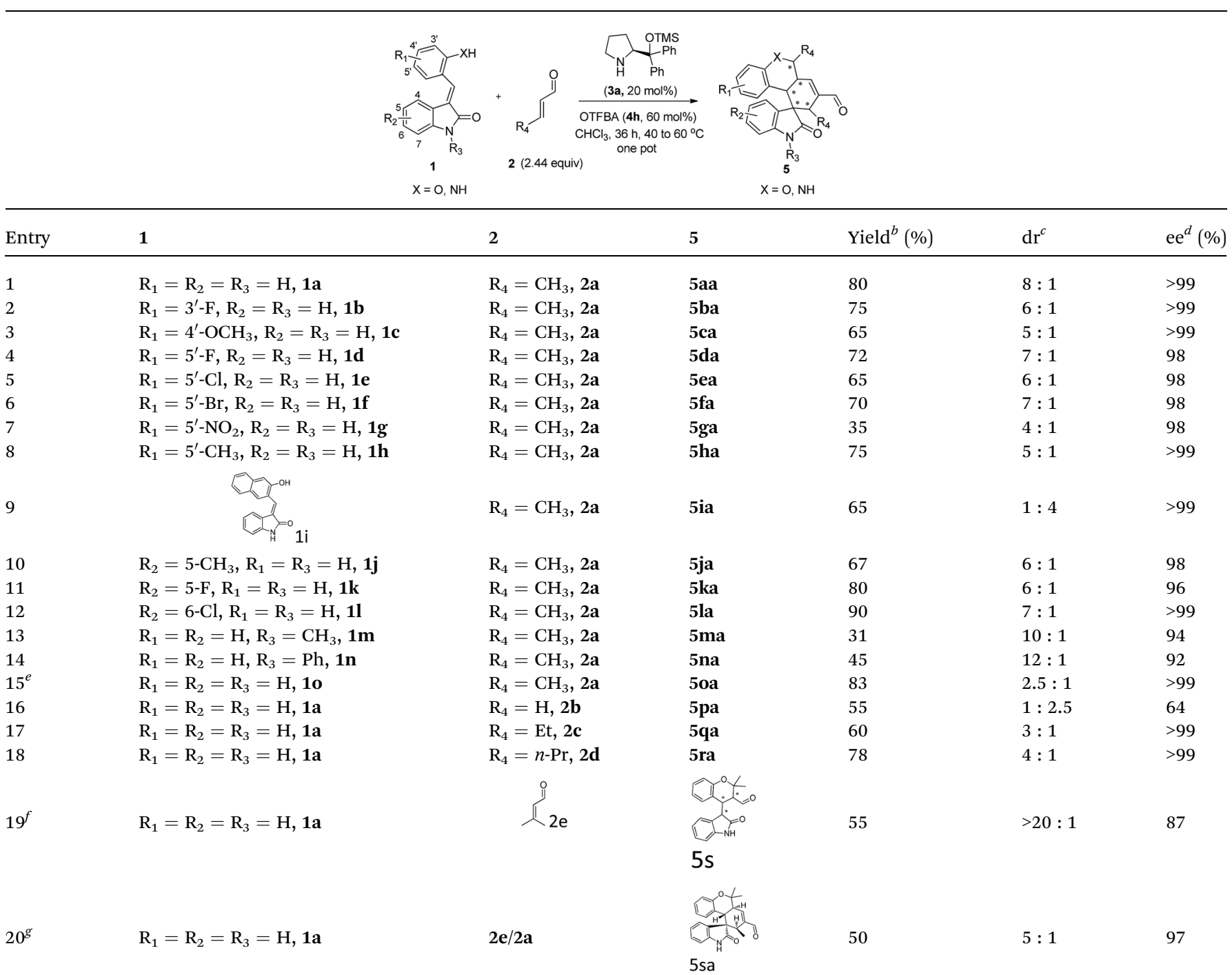

\footnotetext{
${ }^{a}$ Unless otherwise noted, reactions were performed with $0.1 \mathrm{mmol} 1$ and $0.244 \mathrm{mmol} 2$ in the presence of the catalyst $3 \mathrm{a}(20 \mathrm{~mol} \%)$ and the additive $4 \mathrm{~h}(60 \mathrm{~mol} \%)$ in $\mathrm{CHCl}_{3} 1 \mathrm{~mL}$ at $40^{\circ} \mathrm{C}$ for $24 \mathrm{~h}$ and then heated up to $60^{\circ} \mathrm{C}$ for $12 \mathrm{~h}, \mathrm{X}=\mathrm{O} .{ }^{b}$ The values are yields of isolated product after silica gel column chromatography. ${ }^{c}$ Determined by ${ }^{1} \mathrm{H}$ NMR on the crude reaction mixture. ${ }^{d}$ Determined by chiral HPLC. ${ }^{e} \mathrm{X}=\mathrm{NH} .{ }^{f} 2$ equiv. of $2 \mathrm{e}$ was involved in the reaction at $40{ }^{\circ} \mathrm{C}$ for $24 \mathrm{~h}$ to generate $5 \mathrm{~s} .{ }^{g} 1$ equiv. of $2 \mathrm{e}$ was employed in the reaction at $40^{\circ} \mathrm{C}$ for $24 \mathrm{~h}$ to generate $5 \mathrm{~s}$, and then 1 equiv. of $2 \mathrm{a}$ was added in the reaction at $60^{\circ} \mathrm{C}$ for $12 \mathrm{~h}$ to generate $5 \mathbf{s a}$.
} 
Having established the optimal reaction conditions, we evaluated the scope of the quadruple cascade reaction (Table 2). Different alkylideneoxindoles derived from various substituted oxindole and substituted salicylaldehyde proceeded smoothly, and the corresponding products could be isolated in moderate to high yields (up to $90 \%$ ) with good diastereoselectivities (up to $8: 1$ ) and excellent ee values (up to 99\% ee) (Table 2, entries 1-15). The electronic properties of the substituents at the aromatic ring had no obvious effect on enantioselectivity, but affected the yields and diastereoselectivity strongly. Generally, alkylideneoxindoles with halogen-substituted groups gave higher yields and diastereoselectivities than other substituted groups (Table 2, entries 2, 4-6, 11, 12 vs. 3, 7, 8). The steric hindrance of the substituents also influenced the diastereoselectivity. The introduction of more sterically naphthalene ring to alkylideneoxindoles proceeded smoothly but provided the domino product of other configuration (Table 2, entry 9). Moreover, incorporating methyl or phenyl groups on the N1 of alkylidene oxindole led to an improvement in diastereoselectivities to $10: 1$ and $12: 1$, respectively, but the yields of the reaction dropped dramatically (Table 2, entries 13, 14). Interestingly, the Michael addition could be realized when an amine group as a donor was introduced at $2^{\prime}$ position of alkylideneoxindole. The tetrahydroquinoline framework 5oa incorporating a spirooxindole motif was obtained in $83 \%$ yield and $99 \%$ ee (Table 2 , entry 15). The reaction of other aliphatic $\alpha, \beta$-unsaturated aldehydes with representative alkylideneoxindole 1a was also examined (Table 2, entries 16-19). These reactions were performed under the same conditions, and gave the corresponding products in moderate to high yields with moderate diastereoselectivities and excellent ee values (Table 2, entries 16-18). Notably, for 3-methyl-2-butenal was employed, only intermediate $5 \mathbf{s}$ was obtained (Table 2, entry 19). This may be caused by steric hindrance of 2e. On the other hand, we hope to introduce more substitution diversity into spirocyclic products. After the Michael-Michael reaction of $1 \mathrm{a}$ and 1 equiv. of $2 \mathrm{e}$ conducted at $40{ }^{\circ} \mathrm{C}$ for $24 \mathrm{~h}$, from which intermediate was generated and isolated. Then 1 equiv. of $\mathbf{2 a}$ was added to continue the cascade Michael-aldol condensation sequences. The polycyclic spiro-fused carbocyclicoxindoles 5sa was directly obtained with excellent enantioselectivity while the yields were fair due to more possible reaction pathways (Table 2, entry 20).

Further examination of the substrate focused on the alkylideneindanedione 1t. As illustrated in Scheme 2, the one pot quadruple cascade reaction of substrate $\mathbf{1 t}$ and $\mathbf{2 a}$ proceed smoothly and gave the polycyclic spiro-fused carbocyclicoxindoles 5 ta with a spiro quaternary center and four chiral centers.
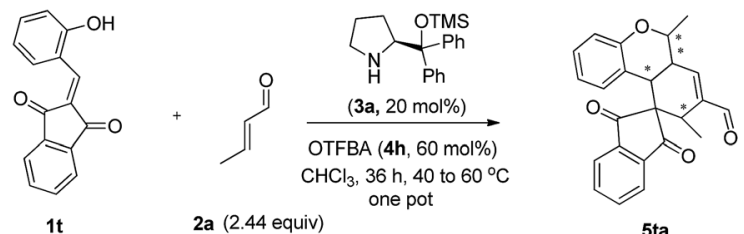

5 ta

yield: $70 \%$, Dr: $2: 1$, ee: $>99 \%$

Scheme 2 Further expanding the scope to alkylideneindanedione.

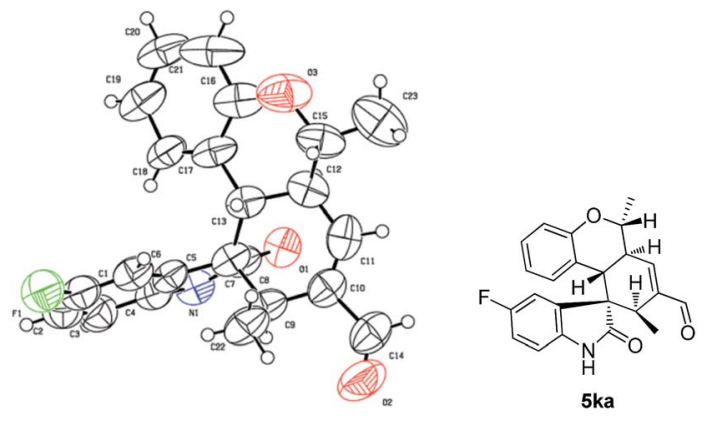

Fig. 2 X-ray structure of enantio-pure $5 \mathrm{ka}$.

The absolute configuration of 5ka was assigned by CuKa X-ray single crystal diffraction analysis (Fig. 2), ${ }^{\mathbf{1 0}}$ and the stereochemistry of other products $\mathbf{5 a a - 5 h a , ~} \mathbf{5 j a - 5 0 a , ~ 5 q a - 5 s a ~}$ was assigned by analogy and specific rotation values. To account for the stereoselectivity of this transformation, we propose a plausible mechanism, as depicted in Scheme 3. As starting material $\mathbf{1 k}$, there is a facial selectivity in the first oxoMichael addition step of the cascade. The iminium-activated crotonaldehyde $\mathbf{2 a}$ is attacked on its $R e$ face by the hydroxyl group (TS-A) generating intermediate enamine $\mathbf{B}$, then reacts in a Michael addition to give cyclic intermediate $\mathbf{C}$, which can again act as nucleophiles to another equivalent of the activated $\alpha, \beta$-unsaturated aldehyde from the $R e$ face under the control of catalyst (TS-D). The third Michael addition step leads to intermediate $\mathbf{E}$, which is unstable and easily reacts through an intramolecular aldol condensation under the reaction conditions, providing product 5ka and regenerating the catalyst.

Finally, in order to identify potential bioactivity of these novel compounds, some selected polycyclic spiro-fused carbocyclicoxindoles $\mathbf{5}$ were investigated for inhibition of cell

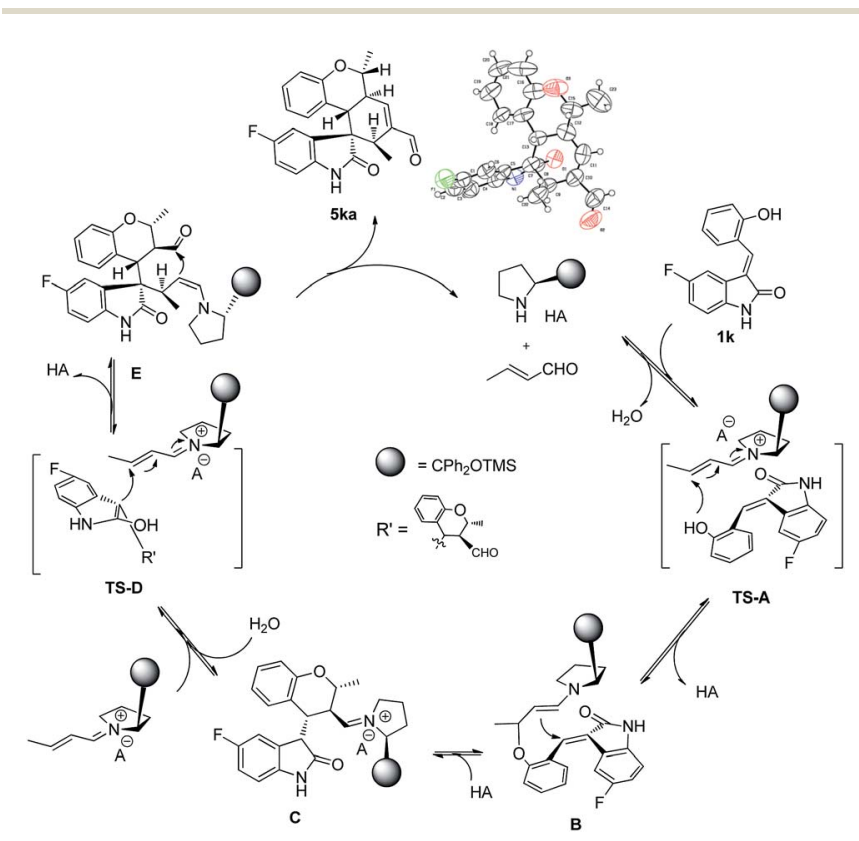

Scheme 3 Plausible reaction mechanism. 
proliferation against human cancer cell line. The preliminary results reveal that compound 5ia performed broad-spectrum antitumor activities against MCF-7, MDA-MB-231, H1975 and FaDu cancer cell lines with $\mathrm{IC}_{50}$ values in the low micromolar range (MCF-7 $\mathrm{IC}_{50}=9.2 \mu \mathrm{M}$, MDA-MB-231 $\mathrm{IC}_{50}=11.5 \mu \mathrm{M}$, $\mathrm{H} 1975 \mathrm{IC}_{50}=14.1 \mu \mathrm{M}$ and $\left.\mathrm{FaDu} \mathrm{IC}_{50}=13.7 \mu \mathrm{M}\right)$. These results indicates this type of polycyclic spiro-fused carbocyclicoxindoles derivatives holds great potential in synthetic and medicinal chemistry.

\section{Conclusions}

In conclusion, we have designed a novel type of multifunctional synthons (E)-3-(2-hydroxybenzylidene) oxindole derivatives. They have been successfully employed in an organocatalytic quadruple cascade reaction with two molecules of $\alpha, \beta$-unsaturated aldehyde through iminium-enamine-iminium-enamine sequential activation. A range of polycyclic spiro-fused carbocyclicoxindoles bearing one spiro quaternary center and five contiguous stereocenters were delivered in moderate to high yields (up to $90 \%$ ) with good diastereoselectivities (up to $8: 1$ ) and excellent ee values (up to $99 \%$ ee). Further expanding the scope of substrate demonstrated the spiro-fused indanedione framework also could be assembled in an effective manner. The absolute configurations of the products were unambiguously confirmed by single crystal X-ray crystallographic analyses and the possible mechanism was proposed for understanding the stereochemistry experimentally observed. Moreover, the results of anti-tumor activity screening indicated that this type of polycyclic spiro-fused carbocyclicoxindole derivatives may find medicinal applications after further structural modulation and biological studies.

\section{Experimental section}

\section{General information}

NMR spectra were recorded on the commercial $400 \mathrm{MHz}$ spectrometer. The chemical shifts were recorded in ppm relative to tetramethylsilane (TMS) and with the solvent resonance as the internal standard. ${ }^{1} \mathrm{H}$ NMR data are reported as follows: chemical shift, multiplicity $(\mathrm{s}=$ singlet, $\mathrm{d}=$ doublet, $\mathrm{t}=$ triplet, $\mathrm{q}=$ quartet, $\mathrm{m}=$ multiplet, $\mathrm{dd}=$ doublet of doublet, $\mathrm{dt}=$ doublet of triplet, $\mathrm{dq}=$ doublet of quartet), coupling constants $(\mathrm{Hz})$, integration. ${ }^{13} \mathrm{C} \mathrm{NMR}$ data were collected at $100 \mathrm{MHz}$ with complete proton decoupling. Enantiomeric excesses (ee) were determined by chiral HPLC analysis on DAICEL CORPORATION AS-H and AD-H columns in comparison with the authentic racemates. Optical rotations were reported as follows: $[\alpha]_{\mathrm{D}}^{\mathrm{T}}(c: \mathrm{g} /$ $100 \mathrm{~mL}$, in solvent). ESI-HRMS spectra were recorded on a commercial apparatus and methanol was used to dissolve the sample. Solvents were commercially available and used directly without further purification. Several substituted oxindoles were prepared according to the literatures and references therein. The MTT method was used to evaluate the antiproliferative activities of the synthesized polycyclic spiro-fused carbocyclicoxindole derivatives. These cell lines (MCF-7, MDA-MB-231, $\mathrm{H} 1975$, FaDu) were obtained from ATCC.
General procedure for asymmetric organocatalytic quadruplecascade reaction of alkylideneoxindoles with enal (5aa-5sa)

$\alpha, \beta$-Unsaturated aldehydes $2(0.244 \mathrm{mmol})$ was added to a dry tube containing a suspension of substituted (E)-3-(2-hydroxybenzylidene)oxindole $1(0.1 \mathrm{mmol}), \alpha, \alpha$-L-diphenylprolinol trimethylsilyl ether 3a (20 mol\%), 2-(trifluoromethyl)benzoic acid 4h $(60 \mathrm{~mol} \%)$ and $\mathrm{CHCl}_{3} 1 \mathrm{~mL}$. The mixture was stirred at $40{ }^{\circ} \mathrm{C}$ for $24 \mathrm{~h}$ and then heated up to $60{ }^{\circ} \mathrm{C}$ for $12 \mathrm{~h}$. The reaction mixture was subjected to silica gel column chromatography to yield the corresponding product.

\section{Acknowledgements}

We appreciate the National Natural Science Foundation of China (No. 81573290, U1603123 and 81202403). We also thank Sichuan University Analytical \& Testing Center for NMR analysis.

\section{Notes and references}

1 (a) A. P. Antonchick, C. Gerding-Reimers, M. Catarinella, M. Schürmann, H. Preut, S. Ziegler, D. Rauh and H. Waldmann, Nat. Chem., 2010, 2, 735; (b) S. M. Rajesh, S. Perumal, J. C. Menendez, P. Yogeeswari and D. Sriram, Med. Chem. Commun., 2011, 2, 626; (c) V. V. Vintonyak, K. Warburg, H. Kruse, S. Grimme, K. Hübel, D. Rauh and H. Waldmann, Angew. Chem., Int. Ed., 2010, 49, 5902; (d) J. J. Badillo, N. V. Hanhan and A. K. Franz, Curr. Opin. Drug Discovery Dev., 2010, 13, 758; (e) G. Kumari, Nutan, M. Modi, S. K. Gupta and R. K. Singh, Eur. J. Med. Chem., 2011, 46, 1181; (f) K. Ding, Y.-P. Lu, Z. Nikolovska-Coleska, S. Qiu, Y.-S. Ding, W. Gao, J. Stuckey, K. Krajewski, P. P. Roller, Y. Tomita, D. A. Parrish, J. R. Deschamps and S. M. Wang, J. Am. Chem. Soc., 2005, 127, 10130; $(g)$ K. Ding, Y. Lu, Z. Nikolovska-Coleska, G. Wang, S. Qiu, S. Shangary, W. Gao, D. Qin, J. Stukey, K. Krajewski, P. P. Rollera and S. Wang, J. Med. Chem., 2006, 49, 3432; (h) M. Tsuda, Y. Kasai, K. Komatsu, T. Sone, M. Y. Tanaka and J. Kobayashi, Org. Lett., 2004, 6, 3087; (i) T. J. Greshock, A. W. Grubbs, P. Jiao, D. T. Wicklow, J. B. Gloer and R. M. Williams, Angew. Chem., Int. Ed., 2008, 47, 3573.

2 For recent reviews: (a) N. R. Ball-Jones, J. J. Badillo and A. K. Franz, Org. Biomol. Chem., 2012, 10, 5165; (b) G. S. Singh and Z. Y. Desta, Chem. Rev., 2012, 112, 6104; (c) D.-J. Cheng, Y. Ishihara, B. Tan and C. F. Barbas III, ACS Catal., 2014, 4, 743; (d) R. Rios, Chem. Soc. Rev., 2012, 41, 1060; (e) A. Moyano and R. Rios, Chem. Rev., 2012, 112, 6104; (f) C. M. R. Volla, I. Atodiresei and M. Rueping, Chem. Rev., 2014, 114, 2390.

3 For selected examples of double and triple cascade reactions to spiro-fused cyclic frameworks containing 2-oxindoles: $(a)$ L.-L. Wang, L. Peng, J.-F. Bai, Q.-C. Huang, X.-Y. Xu and L.-X. Wang, Chem. Commun., 2010, 46, 8064; (b) B. Tan, N. R. Candeias and C. F. Barbas III, Nat. Chem., 2011, 3, 473; (c) K. Albertshofer, K. E. Anderson and C. F. Barbas 
III, Org. Lett., 2012, 14, 5968; (d) G. Bencivenni, L.-Y. Wu, A. Mazzanti, B. Giannichi, F. Pesciaioli, M.-P. Song, G. Bartoli and P. Melchiorre, Angew. Chem., Int. Ed., 2009, 48, 7200; (e) C. Cassani, X. Tian, E. C. Escudero-Adán and P. Melchiorre, Chem. Commun., 2011, 47, 233; (f) Q. Wei and L.-Z. Gong, Org. Lett., 2010, 12, 1008; (g) Y.-B. Lan, H. Zhao, Z.-M. Liu, G.-G. Liu, J.-C. Tao and X.-W. Wang, Org. Lett., 2011, 13, 4866; (h) Y.-M. Li, X. Li, F.-Z. Peng, Z.-Q. Li, S.-T. Wu, Z.-W. Sun, H.-B. Zhang and Z.-H. Shao, Org. Lett., 2011, 13, 6200; (i) B. Wu, G.-G. Liu, M.-Q. Li, Y. Zhang, S.-Y. Zhang, J.-R. Qiu, X.-P. Xu, S.-J. Ji and X.-W. Wang, Chem. Commun., 2011, 47, 3992; (j) X.-W. Dou and Y.-X. Lu, Chem.-Eur. J., 2012, 18, 8315; (k) Y.-M. Cao, X.-X. Jiang, L.-P. Liu, F.-F. Shen, F.-T. Zhang and R. Wang, Angew. Chem., Int. Ed., 2011, 50, 9124; (l) X. Companyó, A. Zea, A.-N. R. Alba, A. Mazzanti, A. Moyano and R. Rios, Chem. Commun., 2010, 46, 6953; (m) A.-N. R. Alba, A. Zea, G. Valero, T. Calbet, M. Font-Bardia, A. Mazzanti, A. Moyano and R. Rios, Eur. J. Org. Chem., 2011, 1318; (n) W.-B. Chen, Z.-J. Wu, Q.-L. Pei, L.-F. Cun, X.-M. Zhang and W.-C. Yuan, Org. Lett., 2010, 12, 3132; (o) X.-H. Chen, Q. Wei, S.-W. Luo, H. Xiao and L.-Z. Gong, J. Am. Chem. Soc., 2009, 131, 13819; (p) F. Pesciaioli, P. Righi, A. Mazzanti, G. Bartoli and G. Bencivenni, Chem.-Eur. J., 2011, 17, 2842; (q) A. Noole, N. S. Scucman, M. A. Kabeshov, T. Kanger, F. Z. Macaev and A. V. Malkov, Chem.-Eur. J., 2012, 18, 14929; (r) W.-S. Sun, G.-M. Zhu, C.-Y. Wu, L. Hong and R. Wang, Chem.-Eur. J., 2012, 18, 6737; (s) K. Jiang, Z.-J. Jia, S. Chen, L. Wu and Y.-C. Chen, Chem.-Eur. J., 2010, 16, 2852.

4 D. Enders, M. R. M. Hüttl, C. Grondal and G. Raabe, Nature, 2006, 441, 861.

5 (a) M. Rueping and C. M. R. Volla, RSC Adv., 2011, 1, 79; (b) A. Raja, B.-C. Hong and G.-H. Lee, Org. Lett., 2014, 16, 5756; (c) B.-C. Hong, P. Kotame, C.-W. Tsai and J.-H. Liao, Org. Lett., 2010, 12, 776; (d) C. Joie, K. Deckers, G. Raabe and D. Enders, Synthesis, 2014, 46, 1539; (e) T. Chanda, S. Chowdhury, B. J. Ramulu, S. Koley, R. C. F. Jones and M. S. Singh, Tetrahedron, 2014, 70, 2190; (f) P. Kotame, B.-C. Hong and J.-H. Liao, Tetrahedron Lett., 2009, 50, 704; (g) N. Erdmann, A. R. Philipps, I. Atodiresei and D. Enders, Adv. Synth. Catal., 2013, 355, 847; $(h)$ L.-Y. Liu, Y.-N. Zhu, K.-M. Huang, B. Wang, W.-X. Chang and J. Li, Eur. J. Org. Chem., 2014, 4342; (i) F.-L. Zhang, A.-W. Xu, Y.-F. Gong, M.-H. Wei and X.-L. Yang, Chem.-Eur. J., 2009, 15, 6815; (j) D. Enders, A. Greb, K. Deckers, P. Selig and C. Merkens, Chem.-Eur. J., 2012, 18, 10226; (k) M. Rueping, K. Haack, W. Ieawsuwan, H. Sundén, M. Blanco and F. R. Schoepke, Chem. Commun., 2011, 47, 3828; (l) D. Enders, C. Wang, M. Mukanova and A. Greb, Chem. Commun., 2010, 46, 2447; ( $m$ ) K. Jiang, Z.-J. Jia, X. Yin, L. Wu and Y.-C. Chen, Org. Lett., 2010, 12, 2766.

6 N. R. Ball-Jones, J. J. Badillo and A. K. Franz, Org. Biomol. Chem., 2012, 10, 5165.

7 A.-B. Xia, C. Wu, T. Wang, Y.-P. Zhang, X.-H. Du, A.-G. Zhong, D.-Q. Xu and Z.-Y. Xu, Adv. Synth. Catal., 2014, 356, 1753.

8 (a) N. Z. Burns, P. S. Baran and R. W. Hoffmann, Angew. Chem., Int. Ed., 2009, 48, 2854; (b) B. M. Trost, Science, 1991, 254, 1471; (c) P. A. Wender, V. A. Verma, T. J. Paxton and T. H. Pillow, Acc. Chem. Res., 2008, 41, 40; (d) P. G. Bulger, S. K. Bagal and R. Marquez, Nat. Prod. Rep., 2008, 25, 254; (e) J. Kim and M. Movassaghi, Chem. Soc. Rev., 2009, 38, 3035.

9 For the synthesis of multifunctional substrates $\mathbf{1}$, see the ESI. $\dagger$

10 Crystallographic data of 5ka reported in this manuscript have been deposited with Cambridge Crystallographic Data Centre as supplementary publication no. CCDC-1040723. $\dagger$ 